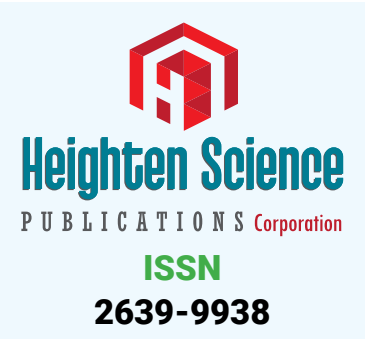

*Address for Correspondence: Sergei V Jargin People's Friendship University of Russia, Clementovski per 6-82, 115184 Moscow, Russia, Tel: +7 495 9516788; Email: sjargin@mail.ru

Submitted: 16 January 2018

Approved: 24 January 2018

Published: 25 January 2018

Copyright: @2018 Jargin SV. This is an open access article distributed under the Creative Commons Attribution License, which permits unrestricted use, distribution, and reproduction in any medium, provided the original work is properly cited

Check for updates
Letter to Editor

\section{Alcohol-related poisonings in Russia: Obfuscated facts}

\author{
Sergei V Jargin* \\ People's Friendship University of Russia, Russian Federation, Clementovski per 6-82, 115184 \\ Moscow, Russia
}

The problem of the alcohol misuse in Russia is well known; but there is a tendency to exaggerate it, which seems to be used to disguise shortages of the healthcare and public assistance. In this way, responsibility for the relatively low life expectancy is shifted onto the patients, who are supposed to drink excessively. In parallel, there is a tendency to exaggerate successes of the anti-alcohol campaign (1985-1989) and to trivialize the harm caused by the campaign e.g. mass consumption of surrogates [1]. The bias can be illustrated with the example of papers by Yuri Razvodovsky [2-5]. Yuri asked me per e-mail to write a "friendly" letter to the Editor referring to his article. An excerpt from the correspondence is presented here as documentary evidence (Fig. 1). In reply, I cited the phrase: "The official statistical data do not support the claims that the... anti-alcohol campaign contributed to the dramatic growth in fatal poisonings by non-beverage alcohol surrogates" [4] and commented that I witnessed mass poisonings with window cleaner in 1988. Considering the large scale of the window cleaner sales, it was knowingly tolerated by authorities. Poisonings with methanol and organochlorides (used e.g. in dry cleaning) were known to occur as well. Yuri replied that "there are two realities: one, which we both witnessed, and another-official statistics" (Figure 1). Obviously, Razvodovsky should have discussed in his articles the "realities we both witnessed", i.e. common knowledge and observations, otherwise his papers are misleading.

During the anti-alcohol campaign, consumption of technical liquids and lotions was known and seen to be increased considerably [6]. Many distilleries producing vodka from grain and potatoes were closed and dismantled. After the campaign, technical alcohol met no demand from the stagnating industry. It was generally known and smelled by the drinking public that technical liquids were used for production of beverages legally sold in bottles with usual labels [7]. The astringent taste of technical alcohol was known as it was purloined from some factories, institutes of physics and technology etc. Reportedly, about a half of lethal poisonings by alcohol-containing liquids in the 1990s was caused in some areas by legally sold beverages [8]. These facts are not always realized by foreign scientists, which can be exemplified by the following citation: "...when faced with a branded vodka at the minimum price and a counterfeit vodka, the consumer will always choose the branded vodka" [9]. In fact, consumers are usually unable to distinguish between branded and counterfeit vodka as it is sold at the same shops and looks identical or almost identical. In the 1990s and shortly thereafter, obliquely affixed labels or lax closures were known as attributes of fakes. Today, falsified and authentic products are hardly distinguishable by sight.

Doubting the data and conclusions by Razvodovsky, I asked him to send me a link to the statistics used in his articles. He did not send me the link but replied that the data were partly "provided by colleagues under condition of confidentiality", partly taken from the Russian Statistical Committee http://www.gks.ru. There are no other 


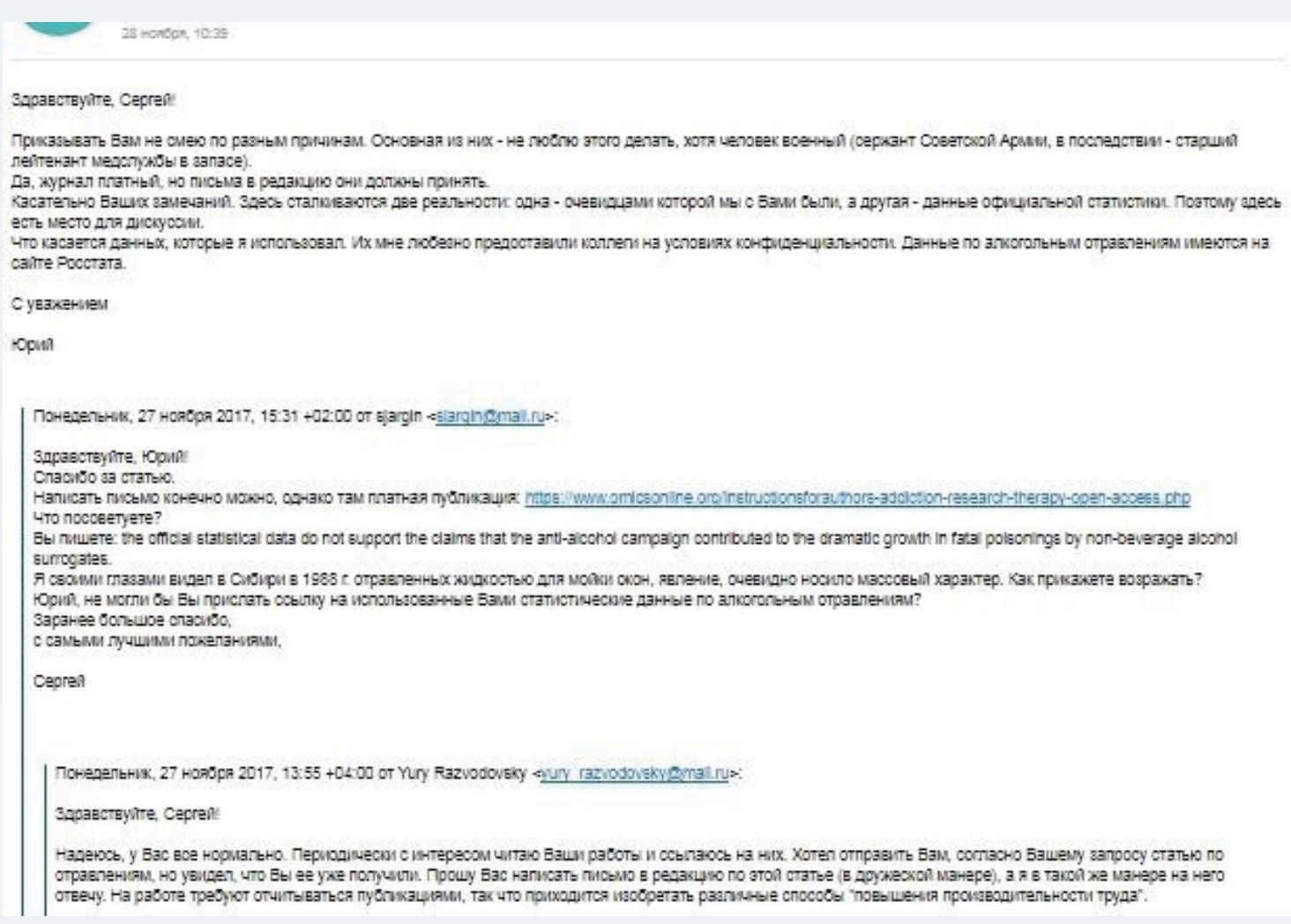

Figure 1: E-mail correspondence Jargin-Razvodovsky cited in the text.

references pertaining to Russian statistics e.g. alcohol induced psychosis incidence rate since 1970, trends of alcohol poisonings since 1956 etc. [3-5]. Using this URL, I was unable to find the data corresponding to statistics and graphs given in the papers by Razvodovsky. Moreover, the graph "vodka affordability" [5] does not agree with official data summarized in a table in [10]. The graph 1 in [3] is also unrealistic. The sales of wine must have been relatively higher than those shown on the graph till approximately 1988 [11]. Besides, in consequence of the anti-alcohol measures that had restricted vodka sales in 1972, there must have been a decrease in vodka and an increase in wine sales; more details are in [1]. If even official statistics cited by Razvodovsky exist, it is not necessarily reliable. Release of information was controlled, sometimes being designed to mislead. For example, between 1984 and 1994, mortality rates in Russia underwent a rapid decline followed by a steep increase. The decrease in mortality including the rate of lethal poisonings [4] might have been initially overstated to highlight successes of the anti-alcohol campaign, being subsequently compensated by overstated mortality figures [12]. There is apparently an artefact behind the "huge variation in Russian mortality" [13]; discussed in [12,14]. Today, the increase in the life expectancy seems to be overstated again to emphasize successes of current policies.

Another questionable concept: "The alcoholic psychoses incidence rate is a reliable indicator of alcohol-related problems at the population level since there is a strong relationship between alcoholic psychoses incidence rate and alcohol consumption per capita" [15]. It should be commented that the alcohol induced psychosis incidence rate may be discussed as an indicator of alcohol consumption in countries with a stable quality of alcoholic beverages but not in Russia, where the quality oscillated considerably over the last 3 decades [1]. By analogy with other complications, psychosis-like conditions may be caused not only by excessive intake of ethanol but also by other substances in poor quality alcoholic beverages and surrogates. Besides, it is known that psychoses have sometimes been overdiagnosed in the former SU [16]. Misdiagnosis as psychosis 
of neurological derangements after ingestion of toxic alcohol-containing liquids cannot be excluded. It was reported that e.g. methanol and carbon tetrachloride produced hallucinations or other symptoms of psychosis [17-19].

After 1991, the increase in mortality considerably exceeded that of alcohol consumption, which grew from 1987 to 1992 by 25-27 \%. For comparison, mortality from alcoholrelated causes increased during the same period 2.5 times and the alcohol induced psychosis incidence rate-2.4 times [20]. Numerous lethal intoxications after the intake of moderate doses were reported [21], while the blood alcohol concentration was relatively low [6,8,21,22]. For example, in Karelia in 1992, the incidence of lethal alcohol poisonings increased 3 times while the average blood alcohol concentration in these cases increased only 1.4 times [6]. For the whole Russian Federation, the mortality rate from alcoholic poisonings increased from 1998 to 2004 by 58 \% and continued growing [22]. These figures witness in favor of toxicity of legally sold beverages. The statement by Razvodovsky: “...alcohol surrogates (industrial spirits, antiseptics, lighter fluid and medications containing alcohol) may be responsible for the extremely high level of fatal alcohol poisonings in Russia" [4] creates impression that consumers deliberately purchase surrogates for drinking. However, it is known by inside observers that consumption of technical liquids, lotions etc. decreased abruptly after the anti-alcohol campaign, when alcoholic beverages have become easily available: numerous new shops and kiosks were opened; there have been no queues as in the Soviet time. The average salary (pension) / vodka price ratio remained several times higher than it had been prior to the anti-alcohol campaign launched in 1985; the price dynamics in relation to salaries and pensions is summarized in a table in the review [10]. The supposition that alcoholics would voluntarily drink surrogates when regular beverages are available is unrealistic. Alcoholics have their experience, they distinguish good and bad products, know their ailments that may exacerbate after the intake of poor-quality alcohol. For example, some alcoholics would never drink beer if it smells technical alcohol. As mentioned above, ethanol from non-edible sources (synthetic and cellulosic) has been broadly used after the anti-alcohol campaign for production of legally sold beverages. Official permissions to use such alcohol were issued during the 1990s [6,23]. Permissions were later revoked; however, in conditions of disregard for some laws and regulations, the use of technical alcohol has been continued.

Current governmental anti-alcohol measures resulted only in moderate oscillations of the real vodka price considering inflation. There has been no significant decrease in physical availability of alcohol: the beverages are sold without queues in numerous shops, while the alcohol sale hours are longer than prior to the anti-alcohol campaign [10]. In the author's opinion, the current decrease in alcohol consumption is mainly caused by the responsible way of life under conditions of the market economy, intimidation and harassment of asocial alcohol-consuming people, crime aimed e.g. at appropriation of their residences etc. [24], which does not predispose to leisure drinking. As for younger people, they seem to overtake the moderate alcohol consumption style prevailing in other countries.

Furthermore, Razvodovsky mentioned in his correspondence that he is a "military man" (Figure 1). Indeed, since the late 1980s, many former party, military and other functionaries as well as their protégés, were introduced into educational and scientific institutions of the former SU. They applied pressure not only to facilitate their own careers but also to impose prescribed ideology [25]. For example, phrases like "Alcohol is the biggest killer in Russia" [4] are suitable to disguise shortages of public healthcare, shifting responsibility for the low life expectancy from authorities onto patients i.e. supposedly self-inflicted diseases due to excessive alcohol consumption. Finally, Razvodovsky mentioned in his correspondence the publication pressure, forcing him to publish as much as possible (Figure 1). Note that science, to be truthful, must be free from all kinds of pressure. Considering the above and previously published comments [11,26-28], numerous papers by Yuri Razvodovsky are biased. 


\section{References}

1. Jargin SV. Popular alcoholic beverages in Russia with special reference to quality and toxicity. $J$ Addiction Prevention. 2017; Ref.: https://goo.gl/RYUqsF

2. Razvodovsky YE. Alcohol-attributable fraction of ischemic heart disease mortality in Russia. ISRN Cardiol. 2013; Ref.: https://goo.gl/HhjrjE

3. Razvodovsky YE. The effect of beverage type on alcoholic psychoses rate in Russia. Alcohol Alcohol. 2015; 50: 200-205. Ref.: https://goo.gl/u8fYWf

4. Razvodovsky YE. Fatal alcohol poisonings and poisonings by other toxic substances in Russia. $J$ Addict Res Ther. 2017; Ref.: https://goo.gl/gshqRL

5. Razvodovsky YE. Affordability of alcohol and alcohol-related outcomes in Russia. J Addict Med Ther 2017; Ref.: https://goo.gl/6QZytf

6. Nemtsov AV. Alcoholic history of Russia: contemporary period.

7. Jargin SV. Questionable information on poisonings by alcohol surrogates. Interdiscip Toxicol. 2016; 9: 83-84. Ref.: https://goo.gl/oRngPd

8. Nuzhnyi VP, Kharchenko VI, Akopian AS. Alcohol abuse in Russia is an essential risk factor of cardiovascular diseases development and high population mortality (review). Ter Arkh. 1998; 70: 57-64. Ref.: https://goo.gl/Ei4ufP

9. Bailey A. Campaign, simulation, or what? President Medvedev's antialcohol initiative, 2009-2012. In: Materials of the Fifth International Scientific-and-Practical Conference "Alcohol in Russia". 2014; 119-124.

10. Jargin SV. Alcohol and alcoholism in Russia: Policies and their effects. Archives Medical Review Journal. 2017; 26: 207-222.

11. Jargin SV. Vodka vs. fortified wine in Russia: Retrospective view. Alcohol Alcohol. 2015; 50: 624-625 Ref.: https://goo.gl/JYL96Y

12. Jargin SV. Cardiovascular mortality in Russia: a comment. Cardiovasc Diagn Ther. 2017; 7: 13-14 Ref.: https://goo.gl/X7VFoA

13. Leon DA, Chenet L, Shkolnikov VM, Zakharov S, Shapiro J, et al. Huge variation in Russian mortality rates 1984-94: artefact, alcohol, or what? Lancet. 1997; 350: 383-388. Ref.: https://goo.gl/okuDXj

14. Jargin SV. Cardiovascular mortality trends in Russia: possible mechanisms. Nat Rev Cardiol. 2015; 12: 740. Ref.: https://goo.gl/swZ8dr

15. Razvodovsky YE. The effect of beverage type on alcoholic psychoses rate in Russia. Alcohol Alcohol. 2015; 50: 200-205. Ref.: https://goo.gl/7ZMgZL

16. Jargin SV. Some aspects of psychiatry in Russia. Int J Cult Ment Health. 2011; 4: 116-120. Ref.: https://goo.gl/9qkrPj

17. Auersperg A, Cid-Araneda A. Threatening delirium and persecution mania. Distinction between methyl alcohol and schizophrenic hallucinations. Nervenarzt. 1970; 41: 209-214. Ref.: https://goo.gl/AFZuLc

18. Souder LR. Psychosis following ingestion of methyl alcohol. Del Med J. 1952; 24: 203-204. Ref.: https://goo.gl/KfVsPF

19. Todd J. "Sniffing" and addiction. Br Med J. 1968; 4: 255-256. Ref.: https://goo.gl/XK2W8F

20. Nuzhnyi VP. Toxicological characteristic of ethyl alcohol, alcoholic beverages and of admixtures to them. Voprosy Narkologii. 1995; 3: 65-74.

21. Govorin NV, Sakharov AV. Alcohol-related Mortality. Tomsk: Ivan Fedorov.

22. Davydov MI, Zaridze DG, Lazarev AF, Maksimovich DM, Igitov VI, et al. Analysis of mortality in Russian population. Vestn Ross Akad Med Nauk. 2007; 7: 17-27. Ref.: https://goo.gl/9sHCTo

23. Nuzhnyi VP, Rozhanets VV, Savchuk SA. Chemistry and toxicology of ethyl alcohol and beverages on its basis: chromatographic analysis of alcoholic beverages. 2016. Ref.: https://goo.gl/pbFoha

24. Jargin SV. Social vulnerability of alcoholics and patients with alcohol-related dementia: a view from Russia. Alcohol Alcohol. 2010; 45: 293-294. Ref.: https://goo.gl/Astmwx

25. Jargin SV. Some aspects of medical education in Russia. Am J Med Stud. 2013; 1: 4-7. Ref.: https://goo.gl/tPmHiA 
26. Jargin SV. Alcohol and alcoholism in Russia since 1985 with special reference to the suicide rate. Int J Psychiatry. 2016; Ref.: https://goo.gl/TcS8qu

27. Jargin SV. Some aspects of nonbeverage alcohol consumption in the former Soviet Union. Psychiatry J. 2015; Ref.: https://goo.gl/nTGcer

28. Jargin SV. Alcoholic beverage type and pancreatitis: A letter from Russia. Pancreas. 2016; 45: 18-19. Ref.: https://goo.gl/CRCCdt 